\title{
COVID-19 PANDEMIC AND INNOVATIVE AGRARIAN ECONOMY
}

\author{
Natig Mirzayev, PhD of Economic Sciences, Associate Professor \\ Lankaran State University \\ Lankaran, Azerbaijan
}

The COVID - 19 pandemic has had and continues to have a profound effect on all areas of our lives. One of the main areas affected by the pandemic is agriculture. The article emphasizes the need to apply science-intensive technologies and expand innovative activities to ensure sustainable development of agriculture in the current pandemic. The importance of new generation technologies in accelerating the innovative development of the agricultural sector is also studied. Positive results have been obtained on issues that need to be solved when organizing and developing an economy based on an innovation system in the agricultural sector in a pandemic.

Keywords: agricultural sector, innovation, COVID-19 pandemic, entrepreneurship, digital transformation, economic activity.

Problem statement. Various economic processes in the modern world, as well as the great disaster pandemic COVID - 19, have harmed all sectors of the economy on a global scale. Such an undesirable event has affected our Republic as well. It should be noted that due to the outbreak of the COVID - 19 pandemic, oil prices in world oil markets in 2020 fell significantly. Unlike other sectors, there is no visible demand for fuel and energy in agriculture.

It should be noted that in most of the developed countries of the world, about $20-25 \%$ of the labor force is employed in the field of high technologies, science, and education. For example, Switzerland, Sweden, and the United States ranked first in the 2020 Global Innovation Index. Azerbaijan ranks 82 nd in this rating. In Switzerland, which ranks first in the ranking, a highly skilled workforce plays an important role in the country's economic development. Research funded by the public and private sectors further improves the business environment in the country and stimulates support for new projects. The bulk of the financial support is provided by the private sector.

The purpose of the innovation is to change the object of management, to achieve a new scientific, technical, economic, and social effect. Innovation is assessed as the commercialization of scientific knowledge, embodied as new or improved products (services), techniques, technologies, organization of production, and management, and has various effects. $[4$, p. 8$]$

Under current conditions, the whole world is trying to further strengthen the innovation environment and transform itself into a digital economy. It should be noted that:

1. digitalization, which today penetrates all life spheres that is digital transformations are taking place under the influence of a pandemic;

2. we have to look actually at digital transformation, which we recognize as a process of broad integration of digital technologies into business, in a broader sense today due to the pandemic.

Analysis of actual research. Preliminary analysis showed that innovative activity in the agricultural sector brings the following benefits: economic, social, environmental, technical, technological, trade, budget, etc.

There are three mutually and interdependent ways of innovative development of agriculture in current conditions:

1. Investment in human capital - priority development of agrarian education, fundamental and applied research organizations, creation of a database on innovations, as well as the creation of an information and consulting system serving agricultural producers;

2. Investment in biological resources increasing soil fertility and productivity of agricultural production through the application of innovative methods;

3. Investment in new technology is the investment in the development of technologies. They can improve the technical and technological potential of agriculture, dramatically increase labor productivity and efficiency of agricultural activities through the use of energy conservation equipment 


and resource-saving equipment, and high
technologies. $[5$, p. $77-81]$

Azerbaijan is one of the two countries in the world that offer Mobile Residency. Mobile Residency, provided through the Digital Commerce Hub, is a public-private partnership project that allows anyone to access many e-services from wherever they are.

Digital transformations are the focus of the top government. On January 6, 2021, the President of the Republic of Azerbaijan signed a decree on the establishment of the "Center for Analysis and Coordination of the Fourth Industrial Revolution" under the Ministry of Economy. The UN appeal in March 2020 stated that the use of digital technologies in the fight against Covid - 19 is inevitable. Many countries have tightened control over their crushing space-time neutron (media).

The development of new regulations is on the agenda. As a digital technology, the Internet of Things (IoT) provides a platform that allows health authorities to monitor the COVID - 19 pandemic.

It is no coincidence that cloud services are considered a necessary factor for sustainable online activity during the pandemic. These factors include: " channel capacity in the home network, the capacity of the Internet channel depending on the server equipment, software, cloud service capabilities"

In the West, "Online Nation 2020 Report: $88 \%$ of current news on social networks is dedicated to the coronavirus. They want to increase the confidence in distorted news by using mathematical statistics. In the Western media, the figures for the coronavirus were exaggerated 142 times last year compared to official statistics. [7]

The reality is that the relevant legal framework is being formed and developed in developed countries. For example, in France, the law "On Confidence in the Digital Economy" has been in force since 2004. The law regulating digital economic relations in the UK has been in force since 2010. In 2017, in addition, the law "On Digital Economy" was adopted. These examples can certainly be multiplied. Thus, in developed countries, the relevant legislation has been enacted. The European Union is currently working to unify the relevant legal norms.

The purpose of the article. In the context of the ongoing COVID-19 pandemic in the global economy, the main goal is to identify the problems that need to be solved when organizing and developing the agricultural sector in the country based on an innovation system.

Presentation of the main material. Innovation means new scientific and technical ideas, new products, new technologies, new production processes, the opening of new markets. Innovation is the result of scientific and technical activity in the form of a new or improved product ( good or service ) or technology. The main feature of the innovation is its application. A new or improved product is considered an innovative product only after it enters the market. [8]

Innovation as a social category lies in the fact that almost all inventions are aimed at reducing the cost of energy, human labor, attracting new productive forces in production, increasing the efficiency of labor and production, and improving product quality. It leads to increased production and consumption, helps to improve the quality of life, helps maintain a balance between supply and demand, production and consumption by improving product quality, reducing costs, and improving production.

Giving preference to the institutional context of innovation, K. Freeman noted that the National Innovation System (NIS) is a network of institutional structures that create, change and promote the diffusion of new technologies, activities, and interactions in public and private sectors of the economy. These institutions (institutions) include both the organizations responsible for conducting the research and "copies of activities that help organize and manage the resources available at the enterprise and country level."

In accordance with the Decree of the President of the Republic of Azerbaijan dated December 19, 2018, the liberalization of the provision of the agricultural sector with machinery has been carried out. Techniques from different companies are leased to farmers with certain discounts $(40 \%)$. The application of innovations, digitalization is under the influence of the pandemic.

The impact of the COVID - 19 pandemic on a digital transformation can be summarized as follows:

1. as quarantine conditions are tightened, the use of digital technologies is expanding and activities in the digital environment are intensifying. This tendency is also found in public life;

2. the situation is different in the economic environment;

3. the doubts we have noted, of course, are reflected in the pace and proportion of the formation of the digital economy;

4. however, there are more fundamental trends in the development of the digital sector of the economy, driven by intrinsic motives;

5. these trends have more to do with economic interests than with conditions created by the pandemic. [1]

Factors of economic activity play an important role in economic processes occurring in a pandemic:

1. It seems that the current processes in the world economy are maneuvering between economic activity and human health.

2. It is taken into account that prohibitions contrary to economic laws usually do not work 
effectively. Therefore, economic activity factors are taken into account in decisions on pandemic-related restrictions.

3. It is not difficult to see that such a situation expands the scope of digital technologies.

It should be noted that the article "Digital Transformation: 4 Ways to Plan a Normal Life After a Pandemic" by a very experienced expert like Bernie Gracy suggests the following:

- proper finance;

- correct tools;

- correct selection of staff;

- the right decisions on the brand." [6]

The author recommends that the correctness of finances, tools, staff, and decisions be assessed in terms of the pandemic impact of digital transformations.

As a result of the successful, purposeful policy pursued in Azerbaijan, which has chosen the path of active integration into the world economic system, the formation of the economy has created favorable conditions for further business activity, the rapid development of the oil and non-oil sectors, poverty reduction, reliable social protection. has significantly improved the situation.

However, given the COVID - 19 pandemic, the global economic crisis, and other ongoing economic processes, the organization of an innovative economy to ensure the competitiveness and sustainability of the agricultural sector, which is an important sector of the Azerbaijani economy, is a requirement of the day.

One of the priorities of the economic policy of the Azerbaijani government is to accelerate the transition to an innovative economy in modern times, the application of the most advanced technologies in our country in line with the line of modernization and, consequently, the implementation of regional programs. This is one of the most important issues in the creation of an innovation system in the agricultural sector. Because recently special attention is paid to the development of the agricultural sector in the country. The country's strategic plans include the development of the agricultural sector, increasing food production, and ensuring food security. Achieving the development of the agrarian sector is one of the main directions of the country's economic diversification strategy.

The economic reforms implemented are proof of this. "The share of the agricultural sector in the country's labor market is more than $35 \%$. However, the share of this sector in the country's GDP per capita is low (6.0\%)." [9] It should also be taken into account that the innovative system in the agricultural sector, unlike other areas, is applied in a unique way. Such a difference is mainly due to the need for a special approach to the field. As mentioned above, food security in the country is directly dependent on this area, the share of workers in this area in the labor market is high, and so on. factors can be cited as the main reasons for this. Ensuring the innovative development of Azerbaijan's agricultural sector can make a positive contribution to the development of the non-oil sector as a whole. This factor will also increase the share of the agricultural sector in GDP per capita.

There are a number of problems in the agricultural sector. So that:

- infrastructure and production technologies are at a low level;

- access to local products to world markets is limited;

- poor coordination between producers and those involved in this activity;

- poor coordination of the market of agricultural products;

- there are few highly qualified, specially trained, and experienced personnel in the agricultural sector;

- depending on the size, enterprises do not cooperate.

The agrarian strategy implemented in Azerbaijan requires a comprehensive study of various issues of increasing the role of entrepreneurship in the agrarian sector, creating favorable conditions for the effective use of intensive and innovative development factors. From this point of view, it is very important to assess the role of business entities in the field, to determine the features of their strategic management, to coordinate the policy of protection and liberalization of international trade in the national agricultural sector, to justify the effectiveness of the existing system of regulation.

The basis of the development strategy of the agrarian sector should be the issues of stimulating the application of the latest achievements of scientific and technological progress. Scientific and technical progress in the XXI century will not be limited to new means and objects of labor, machines, and technologies, but will include the productive forces, including man himself, on the other hand, new production relations, primarily organizational forms and methods of farming. The highest efficiency of scientific and technical progress in agriculture will be ensured through the use of its latest directions and factors. [3, p. 141]

For more effective cooperation between science, public and private sectors in our country, it is necessary to create appropriate legislation and institution, as well as effective implementation of activities. In addition to financial support in the agricultural sector, the organization will assist in conducting monitoring and further increase the knowledge of entrepreneurs in the field of business. Such an approach will have a positive impact on the 
development of the agricultural sector by increasing its export potential and will further accelerate the formation of an innovative agricultural economy.

In our republic, the Innovation Agency was established under the Ministry of Transport, Communications and High Technologies of the Republic of Azerbaijan, and the Innovation Center was established under the State Agency for Citizen Services and Social Innovations under the President of the Republic of Azerbaijan. In addition, the vital importance of the agricultural sector has led to innovation activity here. "Thus, 12 agricultural research institutes operating in the country, including 7 research institutes included in the structure of the Center for Agrarian Science and Innovation of the Ministry of Agriculture, Agrarian Research Center, Araz Scientific Production Association (Nakhchivan Autonomous Republic), A large part of the 8 regional centers of agrarian science and innovation and about 40 experimental and production bases of research institutes make a valuable contribution to the innovative development of this field." [2, p. 18]

It should be noted that such highly specialized institutions have a direct impact on the development of innovation in the agricultural sector. These bodies manage research and dissemination of results, and coordinate research structures related to the agricultural sector.

Realization of opportunities to increase the economic efficiency of agrarian entrepreneurship in the conditions of development of public-private partnership and diversification of activity is possible only in the conditions of creation of specialized subjects of innovative development in the regions.

The effectiveness of innovative entrepreneurship in the agricultural sector depends on the establishment of specialized entities to carry out innovative activities in the country, including innovation centers, agro-parks, technology parks, and incubators, etc., which implement product and process innovations. depends on the network capacity and distribution area. Thus, the subjects of specialized innovation activities promote the increase of innovation activity in the agro-food industry by strengthening technological, organizational, and information support.

Cluster development is based on criteria such as efficient use of resources and infrastructure, including joint logistics systems, improvement of labor resources (staff training), and joint innovative production activities, aimed at realizing the comparative advantages of agro-industrial integration and specialization. Given that the market orientation of innovations is one of the main conditions for its sustainability, the important role of agro-industrial clusters in promoting entrepreneurship should be emphasized. On the other hand, joint production and commercial activities place quite specific and longterm requirements for the infrastructure of intellectual development. Cluster initiatives, which envisage the realization of resource conservation opportunities, modernization of production infrastructure, and active application of high technologies, create favorable conditions for the development of innovative entrepreneurship in the agricultural sector. These conditions should be conducive to minimizing losses in the movement of resources and finished products.

At present, our country is at the initial stage of innovation development. As we have noted, the main priority of the economic policy of our country is to develop the non-oil sector of the economy.

Due to the priority of strengthening coordination between institutions or organizations engaged in innovative activities, it is very important to promote and produce innovative products based on science, to stimulate free access to the market and their application in production, especially in agricultural production. Of course, the above can be done in exchange for improving the regulatory framework.

Some production factors inhibit and support innovation in agricultural production and processing plants and research centers:

A. Production factors hindering innovation

1. low level of innovation potential;

2. lack of staff;

3. ignorance of technological innovations;

4. ignorance of the markets for new products.

B. Factors of production that support innovation:

1. state procurements;

2. prices;

3. subsidy;

4. information consulting services;

5. coordination in the implementation of innovative programs.

Unfortunately, there are no official or unofficial statistics on how much investment was made in innovation in general and in the agricultural sector before and during the pandemic. We can provide only the following indicators (Table 1). 
Table 1

Structure of the use of investments in fixed assets by main types of production activities (in percent)

\begin{tabular}{|c|c|c|c|c|c|c|c|}
\hline & \multicolumn{9}{|c|}{ Years } \\
\cline { 2 - 8 } & 2005 & 2010 & 2015 & 2016 & 2017 & 2018 & 2019 \\
\hline Agriculture & 0,7 & 4,4 & 2,2 & 2,1 & 3,5 & 4,4 & 4,2 \\
\hline Total & 100,0 & 100,0 & 100,0 & 100,0 & 100,0 & 100,0 & 100,0 \\
\hline $\begin{array}{c}\text { Investments in fixed assets in } \\
\text { agriculture, million manats }\end{array}$ & 40,7 & 431,0 & 355,4 & 325,1 & 617,8 & 764,4 & 769,5 \\
\hline
\end{tabular}

Source: author own elaboration on the basis of materials [9]

The development of the agricultural sector in Azerbaijan, the satisfaction of the country's food needs, and the export of agricultural products to foreign markets are some of the priorities of economic policy. Therefore, the achievement of technological advances in the agricultural sector and the training of highly qualified personnel is one of the most important issues. Regarding the consideration of innovation in the agricultural sector as a systematic approach and the creation of an innovation system, it was noted that our country has great potential and opportunities in the agricultural sector. Based on the experience of other countries, we can say that the application of innovations in the agricultural sector and its development brings a lot of benefits to the country's economy as a whole.

At present, the American, Western European, Israeli and Japanese experience of innovative activities in the agricultural sector is considered to be more advanced. At the same time, according to international experts, the experience gained by Australia, China, and some Latin American countries in various areas of agriculture deserves special attention. At a time when the tendency of agriculture to become a kind of industry is intensifying, the innovation of agrarian entrepreneurship depends on the intensity and stability of inter-sectoral relations, especially on the sustainability of agro-industrial relations, in other words, the level of integration.

The world's economic power centers are also known as areas with a high level of innovative activity in various fields, including the agro-food sector. It is no coincidence that almost 80 percent of the market for innovative products is at the disposal of developed countries.

In Japan, where there is a high level of support for agricultural producers, there have been significant changes in food production policy due to the transition to international diversification. Thus, Japan has had a significant impact on the structure of agrofood development in a large region to ensure national food security by investing heavily in the establishment of joint agro-industrial enterprises, innovative agricultural production, and agroprocessing in developing countries.

Among the People's Republic of China, extensive reforms have been carried out to support state-owned agricultural enterprises and agrarian enterprises in a fully justified selection process. The known results of these reforms can be instructive for post-Soviet countries. The point is that to minimize the negative consequences of "shock therapy", it is the latest experience of the transition from a centralized economy to civilized market relations that is useful for promoting innovative and sustainable entrepreneurship in agriculture.

The experience of different countries in this direction can be listed. Azerbaijan can also achieve high results using the experience of these countries.

Conclusions and prospects for further research. The current crisis caused by the COVID19 pandemic has once again proved that the creation and development of an innovative agrarian economy should be considered as one of the main directions for the country. In this regard, it is very important to increase and support the number of innovative institutions in the country, to promote and give preference to innovative products, as well as to apply for certain tax benefits.

It can be concluded that the following issues are important for the organization and development of the economy in the agricultural sector based on an innovative system:

creation of an effective legislative framework for the innovation system of the agrarian sector of the republic;

- establishment of an organization to coordinate institutions engaged in innovation activities in the agricultural sector;

- formation and improvement of public-private partnership in the field of innovation application;

- provision of financial support and tax incentives by the state to institutions engaged in innovation and research;

- private sector support for institutions involved in these activities; 
- support for the application of innovative methods and scientific research in the agricultural sector. At the same time, increase production efficiency and further strengthen logistics links;
- improving the higher education system of the republic following the developed modern education system and training highly qualified personnel for the agricultural sector.

\section{References:}

1. Balayev Rəsul. (2021). Pandemiya və rəqəmsal transformasiyalar. [Pandemic and digital transformation]. ADiU-UNEC. "EIm günləri". Bakı, 15-30 mart [in Azerbaijani]. URL: http://news.unec.edu.az/xeber/100-elm/7280-bold-red-unec-de-elm-gunlerikechirilir-bold-red-Title from the screen.

2. Mirzəyev N. S. (2017), Azərbaycanda taxılçılıq sahəsində sahibkarlıq subyektlərinin faəliyyət istiqamətləri. [Areas of activity of entrepreneurial entities in the field of grain growing in Azerbaijan]. Monoqrafiya. "Elm və təhsil" nəşriyyatı. Bakı [in Azerbaijani].

3. Salahov S. V. (2004), Aqrar sahənin dövlət tənzimlənməsi problemləri. [Problems of state regulation of the agricultural sector]. Bakı, "Nurlan", 504 s. [in Azerbaijani].

4. Salahov S. V. (2010), Aqrar sahənin innovasiya yönümlü inkişafının konseptual əsasları. [Conceptual framework for innovative development of the agricultural sector]. "Innovasiyalı kənd təsərrüfatı istehsalının formalaşdırılması problemləri”nə həsr edilmiş beynəlxalq elmi-praktik konfransın materialları. Bakı, Az.ETKTi və Ti, s. 8-18. [in Azerbaijani].

5. Babayeva V. M. (2020), Aqrar sahənin innovasiyalı inkişafının prioritet istiqamətləri. [Priority areas of innovative development of the agricultural sector]. "Kənd təsərrüfatının iqtisadiyyatı” elmi-praktiki jurnal. № 4 (34). Bakı, [in Azerbaijani] URL: agroeconomics.az. - Title from the screen.

6. Bernie Gracie. (2020), Digital transformation: 4 ways to plan a normal life after a pandemic. URL: https://enterprisersproject.com/article/2020/4/digital-transformation-how-plan-post-pandemic - Title from the screen.

7. Online Nation/ (2020), [Èlektronnyj resurs]. URL: https://www.ofcom.org.uk/_data/assets/pdf_file/0027/196407/onlinenation-2020-report.pdf - Title from the screen.

8. The Measurement of Scientific, Technological and Innovation Activities Oslo Manual (2018) GUIDELINES FOR COLLECTING, REPORTING AND USING DATA ON INNOVATION. URL:

http://www.stats.gov.cn/english/pdf/202010/P020201012342666850167.pdf - Title from the screen.

9. State Statistics Service of Azerbaijani URL: https://www.stat.gov.az. - Title from the screen.

\section{Н. Мирзоев. Пандемия COVID - 19 и инновационная аграрная экономика}

COVID - 19 пандемия оказала и продолжает оказывать глубокое влияние на все сферы нашей жизни. Одна из основных областей, затронутых пандемией - это аграрный сектор. В статье подчеркивается необходимость применения наукоемких технологий и расширения инновационной деятельности для обеспечения устойчивого развития сельского хозяйства в условиях нынешней пандемии. Также изучается важность технологий нового поколения в ускорении инновационного развития аграрного сектора.

Получены положительные результаты по вопросам, которые необходимо решать при организации и развитии экономики на основе инновационной системы в аграрном секторе в условиях пандемии.

Ключевые слова: аграрный сектор, инновация, пандемия COVID-19, предпринимательство, цифровая трансформация, экономическая активность.

\section{H. Мірзоєв. Пандемія COVID - 19 і інноваційна аграрна економіка}

Пандемія COVID - 19 має глибокий вплив на всі сфери нашого життя. Однією з основних областей, порушених пандемією, $\epsilon$ аграрний сектор. У статті наголошується на необхідності застосування наукомістких технологій і розширення інноваційної діяльності для забезпечення сталого розвитку сільського господарства в умовах нинішньої пандемії. Також вивчається важливість технологій нового покоління в прискоренні інноваційного розвитку аграрного сектора.

Отримано позитивні результати з питань, які необхідно вирішувати при організації та розвитку економіки на основі інноваційної системи в аграрному секторі в умовах пандемії.

Ключові слова: аграрний сектор, інновація, пандемія COVID-19, підприємництво, цифрова трансформація, економічна активність. 